\title{
A Shift-Share Analysis of Electrical and Electronic Products: An Overview and Assessment of Export Growth of Malaysia
}

\author{
Abdullah-Al-Mamun ${ }^{1}$, Muhammad Khalilur Rahman ${ }^{2}$, Mohamed Taufiq ${ }^{1} \&$ Muzzammir $^{1}$ \\ ${ }^{1}$ Faculty of Economics and Management Sciences, International Islamic University Malaysia Gombak, Kuala \\ Lumpur, Malaysia \\ ${ }^{2}$ Faculty of Business and Accountancy, University of Malaya, Kuala Lumpur, Malaysia \\ Correspondence: Muhammad Khalilur Rahman, University of Malaya, Kuala Lumpur, Malaysia. Tel: \\ 60-3-1234-5645. E-mail: abd_khalil2@yahoo.com
}

Received: December 5, 2014 Accepted: January 26, 2015 Online Published: April 20, 2015

doi:10.5539/ass.v11n10p330 URL: http://dx.doi.org/10.5539/ass.v11n10p330

\begin{abstract}
The study examines the global export market and its prospect for Malaysia's electrical and electronic (E\&E) products. The shift share technique is applied to identify the potential export growth by selected top fifteen countries for the period of 2006-2008 and 2009-2011. The findings of shift-share analysis indicate that the overall market has increased in export value as the market experienced has increased in each country except Japan, Thailand and USA. In addition, the results also reveal that Singapore has the highest growth rate and Cambodia has a comparatively lower rate. This paper discussed about the theoretical implications, conclusion and recommended for future study.
\end{abstract}

Keywords: shift-share, electronic product, export growth, Malaysia

\section{Introduction}

Malaysian economy has experienced a tremendous change by becoming an industrialized country through its rapid industrialization. The strong and the rapid growth of the country's economy in terms of country's exports have been fuelled by the expansion of its manufacturing sector (Rahman, Aflah, Chowdhury, \& Khan, 2014). According to Das (1998), the expansion in manufactured goods for export in the developing countries, has brought more dynamic growth effects. Thus, the range of country's benefits to an economy are becoming more steadier in terms of export earnings, favorable terms of trade, higher rates of investment, and technological progress, which brings the economy closer to international standards. At present, the position of Malaysia is in the world's top 20 trading nations because of the substantial variation which has happened in the late 1980's when Malaysia observed doubled export in its share of the manufacture exports only within a span of five years (MITI, 2002), mainly in the industry of Electrical and electronic (E\&E) in terms of exports. Malaysia has been identified, basically, as an export-oriented country and is seemed as an important component of the Economy of Malaysia.

Electrical and electronic industry is the foremost industry and is the largest contributor in terms of export earnings and employment opportunities. The US, Singapore, Hong Kong, Japan and China are the countries where Malaysia exports their E\&E items mostly. Malaysia earned a total of RM189.49 billion which is 56.6\% of its total exports in the world and remains world's largest contributor among the developing countries. In Malaysia, E\&E achieved a very strong position over the last three decades and shows the light of hope for the investors to establish new manufacturing operations in this industry, as well as to expand and diversify in the existing operations in Malaysia. According to the WTO report, Malaysia was the world's 21st largest exporting country and the 28th leading importer in 2008. All these statistics reflect the rapid expansion of Malaysia's trade. The effect on export of Malaysian E\&E products focus on electric motors and generators (excluding generating sets) (8501), electric generating sets and rotary converters (8502), electrical transformers, static converters (rectifiers) and inductors (8504). This study uses the Constant market share and shift share analysis to assess the Malaysia's export of E\&E compared to the other world economies. Many researches have been conducted by many researchers who considered the competitiveness of commodity exports in Malaysia, namely palm oil (Fatimah \& Roslan, 1988; Mohamad, Fatimah, \& Aziz, 1992), Cocoa and rubber (Nasir, Ghazali, \& Othman, 1993) and E\&E products (Fatimah \& Alias, 1997). Amir (2000) displayed in-depth research on competitiveness 
of Malaysian manufacturing products and factors that influence Malaysia's export competitiveness.

Malaysian exports of E\&E goods are growing in exports over the years, despite the recent decrease between 2008 and 2009. However, it is up to the government and the $\mathrm{E} \& \mathrm{E}$ manufacturers and retailers of such items to promote growth and the implementation of a brand recognition strategy. There are no such Malaysian brands that may be considered globally recognized due to various reasons such as:

(i) Malaysian manufacturers have not been able to match up to the production quality standards of its foreign competitors. This can be seen in the case of Malaysian car maker Proton which, despite getting subsidies and grants from the government has not been able to make its mark as a high quality brand.

(ii) The government has promoted foreign direct investment of companies from Japan, China and Korea to provide for its society instead of concentrating on building on its own home companies. An example is how Malaysia is heavily reliant on Singapore to provide for many of its imports, most of which are consumer goods. This causes increased prices of goods due to import tariffs.

(iii) Japan's strategy for global success may be due to its strategy to provide local goods to its local customers while maintaining high prices locally so as to be able to offer low prices internationally. This provided a competitive edge to Japanese manufacturers exporting their goods, while ensuring that local customers bought from them and provided stable profits. Perhaps it is for Malaysia to learn from such strategies if it is to make its mark internationally.

Although E\&E goods manufacturers worldwide aim to innovate new and advanced technological goods and services for the benefit of their customers as well as to maintain a competitive and proactive strategy of production, it is market innovation that gets less attention but is an equally significant tool in the global merchandising of E\&E goods. This study depicted that shift-share analysis method is used to assess and predict regional development and growth.

In our globalization an international trade is becoming more significant and very large market size for every global business industry. East Asian (EA) economic growth is renowned for its heavy reliance on international trade. Malaysia is also industrializing fast to become a well-known Electricals and Electronics exporter in the international market. However, international competition gets stiffer day by day as globalization of different market gathers momentum. Malaysia is one of the world's major export nations but it has faced some of the major threat as it is surrounded by competitors with different comparative advantage. At one point of the spectrum, are the economies simplified with ample, cheap labor such as China and India while the countries like Taiwan and Korea with strong productivity and innovations are at the opposite end of the spectrum. This sees Malaysia, facing major threats that are causing more worries on its capacity to compete internationally as to whether to improve the quality of its exports sufficiently in order to compete, or whether it can still manage and cope with the costs pressure of both manufacturing and exporting to the world market.

The objective of this study is important to determine some of the consideration which may be regarded as the map of the project. The objective will be based on the data collected and by the final findings. Some objectives of the study are:

a) To analyse the market share of Malaysia Electricals and Electronics exports by using shift share analysis approach in order to assess its competitiveness in the world market.

b) To identify the Malaysian competitive position in Electricals and Electronics exports of the world market from 2007-2011.

c) To examine whether there has been an increase or a decline in Malaysia Electricals and Electronics export performance over 2007-2011 is associated with the decline in Malaysian Competitiveness.

The wave of globalization has led to the rapid transformation of cultures around the world whereas it facilitates the prospect of global marketing around the planet. The uprising culture of trade has provided consumers with more foreign product choices than ever before. International trade has become an important part of business operation for companies. They invest huge amount of money in order to be successful in this challenge. New markets have been established and the demand is increasing for the manufactured electrical and electronics. Export is a type of international trade which is less risky compare to foreign direct investment. The electrical and electronics based products across the globe especially China has received a tremendous growth over the years, ever since its first development. The industry has changed the way of life across the globe. Besides, it also has major effects on international economics. For this reason the significance of the study will help us understand the benefits of exporting in foreign markets. The result of this study will add a value in the area of international business and trade which could also help Malaysian E\&E industry as well as its policy makers to know about the 
strength and weakness of the E\&E export market and thus be able to focus as per the market demand to maintain its steady growth in the world export market.

\section{Literature Review}

The shift-share analysis is a method used to assess and, to some degree, predict regional development and growth. The shift share analysis was apparently originated in early 1940s by Daniel Creamer (Yasin et al., 2004). Then it was later summarized and induced by Dunn (1960). The Shift-share analysis has been used as a tool that partitions the growth of an economic variable in a particular area into various components. The main idea behind is to analyse the growth between each region and national average for checking the region's performance in terms of uniformity that indicates a better position in the industry in aspect of its growth. This method of analysis has commonly been used for relating regional and industrial economic growth as well as examining the structural effect and regional or industrial competitiveness causing the changes in growth over time (Sirakaya, Uysal, \& Toepper, 1995). The shift share method has been popular in its application to different fields which includes regional economic, political economy, marketing, geography, and urban studies for about four decades. The reason for the popularity of this technique is because of its simplicity and ability to overcome the problems inherent in the use of absolute and percentage measures relative to some of the more complex models available to regional analysts (Williamson, 1980).

Shift-share method of analysis has also been a very practical method used in assessing the impacts of industrial restructuring growth on the regional and local economies, as well as providing guidance for industrial targeting, and hence can make an important contribution to the understanding and the selection of key leading industries in the region, which can facilitate forming local industry partnerships (Dinc, 2004). The Shift-share analysis divides a regional economy into three primary mechanisms which are known as national growth, industrial mix, and competitive share. The summation of these three components is equal to the total economic change of the area. Dinc (2005) stated that shift-share analysis reveals total economic change that is attributable to the growth of the national economy, the industrial mix of the region, and the competitiveness of the local industries. It is possible to explore the advantages of the local area, as well as to identify the potential growth of industries that may need further investigation through the interpretation of shift share analysis.

The shift-share or constant market share analysis is a traditional tool to deal with structure effects. Among all other methods, shift-share method is one of the simplest and least expensive techniques for identifying growth rates. Besides trade issues, shift share was usually used to measure the economic and employment growth of a region. But according to regional science literature, this method can be extended to study a large number of economic issues. Shift-share is not a causal analysis and does not, in itself, identify the reasons behind any change in a country's performance as measured by the export differential, such as changes in its domestic cost structure or effective exchange rate. Empirical studies showed that shift-share analysis has been recognized as an efficient method to assess and, to some degree, predict regional development and growth (Ashby, 1968; Chalmers \& Bechelm, 1976; Dunn, 1980; Andrikopoulos et al., 1987; Keil, 1992).

The study by Nicole (2006) "long-term change around Sky Train Stations in Vancouver, Canada: a demographic shift-share analyses", University of British Columbia, Canada. This study tested the long term demographic influence of sky train. Other test Using shift share analysis in conducting a research of inadequate of differences growth rate of employment from different region in Philippine done by Aya-ay and Prantilla (2007). The model also applied to distinguish between mix industry and sole industry has more or less advantage, growth and competitive advantage in labour market. In addition, Banister and Berechman (2000) argued that transit system's success also depend on the country's economy at the time when it is built. However, this research revealed that 'Sky Train' has strong influence on the education and wealth among the residents of the neighbourhoods of Vancouver. Haque (2002) examines of export opportunity and growth of the readymade garments from Bangladesh, He concluded the textile global market need to observe and determine the future of sustainability and growth as well as expanding of readymade cloth industry export of Bangladesh.

\section{Methodology}

\subsection{Data Collection}

This study is mainly based on secondary data. The data has been collected from the web site of "Department of Statistics Malaysia" and "Trade Map". We considered the Malaysian export data of 15 countries, namely Australia, Bangladesh, Brunei, Cambodia, China, Germany, Hong Kong, Indonesia, India, Japan, Saudi Arabia, Singapore, Thailand, United States of America(USA) and Vietnam and three commodities of E\&E among five which STC codes are 8501, 8502 and 8504 . These countries and products were chosen because these countries are the major export markets and the items are important Malaysia's E\&E goods. 


\subsection{Procedure}

The export markets taken for analysis was compared in five areas which are, actual change in the market, expected value of the market, expected change in the market, net shift in the market and the percentage of net shift in the market. Since our export data was for six years (2006-211), we divided it into two terminal periods for analyzing shit share. The market with the highest actual change is the country where Malaysian exports of electrical and electronic goods have performed best. Growth rate for all the markets combined was also calculated by dividing the sum of the exports in the terminal period by the sum of exports in the initial period. A positive figure shows that all the markets have positive growth over the period of six years. Net shift is another tool used to measure performance of the markets and compare them against each other. It is measured by deducting the actual change from the expected change. A positive net shift signify positive shift of the market over the years.

\subsection{Hypothesis}

Hypothesis was developed based on secondary data and the articles used for doing the literature review. The research done by the authors indicate that there is a positive relationship between the amount of market orientation a business uses and the growth in trade between the two. Since export of E\&E products is a competitive market with tight competition among the rivals, it would do well on Malaysia's export competitiveness if it would use a market orientation approach. Therefore, hypothesis is:

H1: Market orientation has a positive and significant impact on Malaysia's E\&E goods exports.

\section{Results and Discussion}

In this research, Malaysian E\&E industry has chosen as the basis of shift share analysis to apprehend the result of future market trend of the export opportunity. The Data was categorized in two parts to simplify the calculation by averaging 2006, 2007 and 2008 in one hand and 2009, 2010 and 2011 on the other. As part of our analysis we have conducted several techniques of shift share analysis on the comprehensive data that consists of 15 countries that Malaysia exports to. The data evaluation results as follows:

\subsection{Actual Change}

Absolute growth value is identified by the actual change for each market. The actual change is simply the difference in values from one time period to another. For instance, $V_{j, t}$ represents the values of the export for market $\mathrm{j}$ at the end of the terminal time period $t$, and $\Delta \mathrm{V}_{\mathrm{j}}$ be the actual change in market $\mathrm{j}$ over the specified period of time. Therefore,

$$
\Delta V_{j}=V_{j, t}-V_{j, t-1}
$$

If $\Delta \mathrm{V}_{\mathrm{j}}>0$ then market experienced an increase and $\Delta \mathrm{V}_{\mathrm{j}}=0$, market remain unchanged as well as if $\Delta \mathrm{V}_{\mathrm{j}}<0$ then it shows market decline It should be noted that $\Delta \mathrm{V}_{\mathrm{j}}>0$ implies only that market $\mathrm{j}$ increased in value. This relationship does not show the growth of this market relative to the other markets. Table 1 presents the actual change of each country.

Table 1. Actual change

\begin{tabular}{lll}
\hline $\mathrm{AC}=$ Actual Change & $\mathrm{AC}, \Delta \mathrm{V}_{\mathrm{j}}$ & Remark \\
\hline Australia & 3121.80 & Increase \\
Bangladesh & 1313.43 & Increase \\
Brunei & 767.87 & Increase \\
Cambodia & 216.62 & Increase \\
China & 3350.84 & Increase \\
Germany & 8584.64 & Increase \\
Hong Kong & 3823.10 & Increase \\
Indonesia & 8199.09 & Increase \\
India & 5219.07 & Increase \\
Japan & $(17001.87)$ & Decline \\
Saudi Arabia & 4258.27 & Increase \\
Singapore & $(61282.44)$ & Decline \\
Thailand & $(4135.64)$ & Decline \\
United States of America & $(42875.81)$ & Decline \\
Vietnam & 4539.79 & Increase \\
\hline
\end{tabular}


Here, using this formula, we have got the difference of both averages from 2006-2008 and 2009-2011 which point out the actual change for this industry on the basis of country that we considered in our research. It is found that the market experienced an increase in every country except Japan, Singapore, Thailand and United States of America (USA) which means that overall market is increasing in export value.

\subsection{Total Growth Rate}

Here $\mathrm{K}$ represents the total value of growth variable for all markets.

$$
K=\frac{\sum_{j=1}^{m} V_{j, t}}{\sum_{j=1}^{m} V_{j, t-1}}
$$

Where,

$\mathrm{K}=0.892608$.

Using this formula we have got the growth rate of $\mathbf{0 . 8 9 2 6 0 8}$ for Malaysian Electrical and Electronics (E\&E) export in our considered 15 countries.

\subsection{Expected Value}

The expected value of the growth valuable at the end of the terminal time period will be $\mathrm{E}\left(\mathrm{V}_{\mathrm{j}, \mathrm{t}}\right)$, if a given market has grown at the rate achieved for all markets. Here $\mathrm{E}\left(\mathrm{V}_{\mathrm{jt}}\right)$ refers to expected value in Table 2 .

$$
E\left(V_{j, t}\right)=K\left(V_{j, t-1}\right)
$$

Table 2. Expected value

\begin{tabular}{llll}
\hline Country & $\mathrm{K}$ & $\left(\mathrm{V}_{\mathrm{j}, \mathrm{t}-1}\right)$ & $\mathrm{E}\left(\mathrm{V}_{\mathrm{j}, \mathrm{t}}\right)$ \\
\hline Australia & 0.892608 & $7,875.57$ & 7029.80 \\
Bangladesh & 0.892608 & 593.95 & 530.16 \\
Brunei & 0.892608 & 530.21 & 473.27 \\
Cambodia & 0.892608 & 481.43 & 429.73 \\
China & 0.892608 & $71,147.53$ & 63506.85 \\
Germany & 0.892608 & $24,568.60$ & 21930.13 \\
Hong Kong & 0.892608 & $77,735.01$ & 69386.89 \\
Indonesia & 0.892608 & $11,184.37$ & 9983.26 \\
India & 0.892608 & $11,870.69$ & 10595.87 \\
Japan & 0.892608 & $150,576.49$ & 134405.78 \\
Saudi Arabia & 0.892608 & $4,686.67$ & 4183.36 \\
Singapore & 0.892608 & $188,379.56$ & 168149.10 \\
Thailand & 0.892608 & $89,530.62$ & 79915.75 \\
United States of America & 0.892608 & $116,556.86$ & 104039.59 \\
Vietnam & 0.892608 & $6,920.46$ & 6177.26 \\
\hline
\end{tabular}

In calculating the expected value, we have found that Singapore has the highest expected value and Japan comes second.

\subsection{Expected Change}

Difference between the expected value and actual value for the market refers to the expected change for particular time frame for each market which depicts:

$$
E\left(\Delta V_{j}\right)=E\left(\Delta V_{j, t}\right)-V_{j, t-1}=V_{j, t-1}(K-1)
$$


Table 3. Expected change

\begin{tabular}{ll}
\hline Country & Expected Change; $\mathrm{E}\left(\Delta \mathrm{V}_{\mathrm{j}}\right)$ \\
\hline Australia & -845.77 \\
Bangladesh & -63.79 \\
Brunei & -56.94 \\
Cambodia & -51.70 \\
China & -7640.68 \\
Germany & -2638.47 \\
Hong Kong & -8348.12 \\
Indonesia & -1201.11 \\
India & -1274.82 \\
Japan & -16170.71 \\
Saudi Arabia & -503.31 \\
Singapore & -20230.46 \\
Thailand & -9614.87 \\
United States of America & -12517.27 \\
Vietnam & -743.20 \\
\hline
\end{tabular}

By performing this formula, we have obtained the negative change in the growth rate of each country of the E\&E market. However, it describes that even it is negative in expected change but it had a steady growth rate which had decreased by period. Here, it indicates that Singapore has the higher growth rate and Cambodia has a comparably lower rate (Table 3 ).

\subsection{Net Shift}

Net shift refers to the difference between the actual change which denoted by $\Delta \mathrm{V}_{\mathrm{j}}$ and the expected change $\mathrm{E}$ $\left(\Delta \mathrm{V}_{\mathrm{j}}\right)$ for each and every market. This difference is denoted as $\mathrm{N}_{\mathrm{j}}$. Thus,

$$
N_{j}=\Delta V_{j}-E\left(\Delta V_{j}\right)
$$

Table 4. Net shift

\begin{tabular}{ll}
\hline Country & $\mathbf{N}_{\mathbf{j}}$ \\
\hline Australia & 3967.57 \\
Bangladesh & 1377.22 \\
Brunei & 824.81 \\
Cambodia & 268.32 \\
China & 10991.52 \\
Germany & 11223.11 \\
Hong Kong & 12171.22 \\
Indonesia & 9400.20 \\
India & 6493.89 \\
Japan & -831.16 \\
Saudi Arabia & 4761.58 \\
Singapore & -41051.98 \\
Thailand & 5479.23 \\
United States of America & -30358.54 \\
Vietnam & 5282.99 \\
Total & $\mathbf{- 0 . 0 2}$ \\
\hline
\end{tabular}

By using this formula, we have differentiated between the actual change and the expected change. It stemmed that most of the countries in the EE market have positive change, but that does not mean that market is experiencing a major increase. It is just the difference between actual and expected change and it does not have any impact on market growth. However, rule of thumb, the net shift value is supposed to be zero. Here, we have got the result -0.02 (Table 4 ) which indicates that it is accurate. 


\subsection{Total Absolute Net Shift}

Total absolute net shift refers to the sum of the positive net shift or the sum of the negative net shift which denoted by "S".

$$
S=\frac{\sum_{j=1}^{m}\left[\Delta V_{j}-E\left(\Delta V_{j}\right)\right]}{2}=\sum_{j=1}^{p} N_{j}^{+}
$$

Where,

Total Absolute Net Shift, S=72241.67

Using this formula, what we have obtained, $\mathrm{S}=72241.67$

4.7 Percentage of Net Shift

Table 5. Percentage of net shift

\begin{tabular}{ll}
\hline Country & $\mathrm{P}_{\mathrm{j}} \%$ \\
\hline Australia & $5.49 \%$ \\
Bangladesh & $1.91 \%$ \\
Brunei & $1.14 \%$ \\
Cambodia & $0.37 \%$ \\
China & $15.21 \%$ \\
Germany & $15.54 \%$ \\
Hong Kong & $16.85 \%$ \\
Indonesia & $13.01 \%$ \\
India & $8.99 \%$ \\
Japan & $-1.15 \%$ \\
Saudi Arabia & $6.59 \%$ \\
Singapore & $-56.83 \%$ \\
Thailand & $7.58 \%$ \\
United States of America & $-42.02 \%$ \\
Vietnam & $7.31 \%$ \\
\hline
\end{tabular}

Table 6. Correlation of the countries

\begin{tabular}{llllllll}
\hline Country & $\begin{array}{l}\text { Initial } \\
\text { period } \\
\left(\mathrm{V}_{\mathrm{j}, \mathrm{t}-1}\right)\end{array}$ & $\begin{array}{l}\text { Terminal } \\
\text { period, } \\
\left(\mathrm{V}_{\mathrm{j}, \mathrm{t}}\right)\end{array}$ & $\begin{array}{l}\text { Actual } \\
\text { Change, } \\
\Delta\left(\mathrm{V}_{\mathrm{j}}\right)\end{array}$ & $\begin{array}{l}\text { Expected } \\
\text { value, } \\
\mathrm{E}\left(\mathrm{V}_{\mathrm{j}, \mathrm{t}}\right)\end{array}$ & $\begin{array}{l}\text { Expected } \\
\text { Change, } \\
\mathrm{E}\left(\Delta \mathrm{V}_{\mathrm{j}}\right)\end{array}$ & $\begin{array}{l}\text { Net } \\
\mathrm{N}_{\mathrm{j}}\end{array}$ & shift, \\
\hline Australia & $7,875.57$ & $10,997.38$ & 3121.80 & 7032.88 & -842.69 & 3967.57 & $\begin{array}{l}\text { Percentage } \\
\text { Netshift, } \mathrm{P}_{\mathrm{j}}\end{array}$ \\
Bangladesh & 593.95 & $1,907.38$ & 1313.43 & 530.40 & -63.55 & 1377.22 & $1.91 \%$ \\
Brunei & 530.21 & $1,298.08$ & 767.87 & 473.48 & -56.73 & 824.81 & $1.14 \%$ \\
Cambodia & 481.43 & 698.05 & 216.62 & 429.92 & -51.51 & 268.32 & $0.37 \%$ \\
China & $71,147.53$ & $74,498.37$ & 3350.84 & 63534.74 & -7612.79 & 10991.52 & $15.21 \%$ \\
Germany & $24,568.60$ & $33,153.25$ & 8584.64 & 21939.76 & -2628.84 & 11223.11 & $15.54 \%$ \\
Hong Kong & $77,735.01$ & $81,558.11$ & 3823.10 & 69417.36 & -8317.65 & 12171.22 & $16.85 \%$ \\
Indonesia & $11,184.37$ & $19,383.46$ & 8199.09 & 9987.64 & -1196.73 & 9400.20 & $13.01 \%$ \\
India & $11,870.69$ & $17,089.76$ & 5219.07 & 10600.53 & -1270.16 & 6493.89 & $8.99 \%$ \\
Japan & $150,576.49$ & $133,574.62$ & $(17001.87)$ & 134464.81 & -16111.68 & -831.16 & $-1.15 \%$ \\
Sau. Arabia & $4,686.67$ & $8,944.94$ & 4258.27 & 4185.20 & -501.47 & 4761.58 & $6.59 \%$ \\
Singapore & $188,379.56$ & $127,097.13$ & $(61282.44)$ & 168222.95 & -20156.61 & -41051.98 & $-56.83 \%$ \\
Thailand & $89,530.62$ & $85,394.98$ & $(4135.64)$ & 79950.84 & -9579.78 & 5479.23 & $7.58 \%$ \\
USA & $116,556.86$ & $73,681.05$ & $(42875.81)$ & 104085.28 & -12471.58 & -30358.54 & $-42.02 \%$ \\
Vietnam & $6,920.46$ & $11,460.25$ & 4539.79 & 6179.97 & -740.49 & 5282.99 & $7.31 \%$ \\
Total & & & & & & -0.02 & 0.00 \\
\hline
\end{tabular}


In this analysis, percentage of net shift is the impact of growth variable for gain or loss of the Malaysian E\&E market for the particular period of time. However, based on this analysis we have found the percentage of net shift (Table 5) for these countries that imports E\&E from Malaysia.

$$
P_{j}=\frac{N_{j}}{S}(100 \%)
$$

\section{Discussion, Conclusion and Recommendation}

This study was conducted by using the Shift Share analysis. The analysis is performed to identify industries considered to have a comparative advantage in that particular area. It is one of the most effective ways to determine the comparative advantage in a specific area. Calculation above shows Malaysia as an export company that supplies E\&E to the above considered main countries worldwide. We have chosen six years' time period to conduct this research and resulted to have $0.00 \%$ of shift share (Table 6). Precisely, Japan, Singapore and USA have a negative correlation with $-1.15 \%,-56.83 \%$ and $-42.02 \%$ respectively. However, the remaining twelve countries showed positive correlation. From above calculation, we can conclude that Hong Kong is the most potential market for E\&E to be exported (16.85\%) for Malaysia. Some other countries like Germany, China and Indonesia are also very close to Hong Kong market by showing $15.54 \%, 15.21 \%$ and $13.01 \%$ net shift respectively. That's why we think by focusing mainly on these countries Malaysia will be able to maintain a productive and effective business in $\mathrm{E} \& \mathrm{E}$ world market.

As we know, nowadays, technology is dominating the world. In other sense, we can say that industrialization remains continue because of electrical and electronic devices' production and improvement of it. In addition, there are many growing industry is currently increasing, and most of them requires E\&E products in the production process. Malaysia still has a long way to go to become a dominant market in the world industry. However, with a growth rate of 0.89 in the major export markets, the future of Malaysia in the manufacturing and export of $E \& E$ seem promising.

Based on the above discussion, we would like to recommend Malaysia to focus their export to Hong Kong, Germany, China and Indonesia. We assume that it will show a high positive impact based on our findings and discussion. As these countries market are growing significantly, and many industries are growing as well. Therefore, it is quite promising that all of these countries especially, Hong Kong will be a good decision to export E\&E products. If we look at other countries, such as Singapore, USA and Japan, they have a large sale in their domestic market, but that does not considered as a factor of their shift share result was still negative at the end of the day with a negative figure of $-56.83 \%,-42.02 \%$ and $-1.15 \%$ respectively which shows a bad sign to export to the countries.

\section{References}

Chandran, V. G., Pandiyan, V., \& Madhavan, K. (2004). Malaysia's export market: Trends, prospects and challenges. National Conference on Research Findings. Riviera Bay Resort, Malacca, Malaysia.

Dieter, M., \& Englert, H. (2007). Competitiveness in the global forest industry sector: An empirical study with special emphasis on Germany. European Journal of Forest Research, 126(3), 401-412. http://dx.doi.org/10. 1007/s10342-006-0159-x

Dinc, M. (2002). Regional and local economic analysis tools. Washington DC: The World Bank.

Foth, N. M. (2010). Long-Term Change Around SkyTrain Stations in Vancouver, Canada: A Demographic Shift-Share Analysis. The Geographical Bulletin, 51, 37-52.

Hadjinicola, G. C., \& Kumar, K. R. (2002). Modeling manufacturing and marketing options in international operations. International Journal of Production Economics, 75(3), 287-304. http://dx.doi.org/10.1016/ S0925-5273(01)00144-X

Haque, A. (2002). Global Marketing of Readymade Garment Products from Bangladesh: Market Prospect and Challenges. Pakistan Journal of Applied Sciences, 2(10), 975-979. http://dx.doi.org/10.3923/jas.2002. 975.979

Kaleka, A. (2002). Resources and capabilities driving competitive advantage in export markets: guidelines for industrial exporters. Industrial Marketing Management, 31(3), 273-283. http://dx.doi.org/10.1016/S0019 -8501(00)00148-6

Mohamad, O., \& Wheeler, C. (1996). Export market strategy, marketing strengths and export performance: Empirical evidence from Malaysia. Malaysia Management Review, 31(2), 18-27. 
Mondal, W. I. (2011). An Analysis of the Industrial Development Potential of Malaysia: A Shift-Share Approach. Journal of Business \& Economics Research (JBER), 7(5).

Muhammad, N. M., \& Yaacob, H. C. (2008). Export Competitiveness of Malaysian Electrical and Electronic (E\&E) Product: Comparative Study of China, Indonesia and Thailand. International Journal of Business and management, 3(7), 65-75.

Plotnikova, M., Wadeson, N., \& Ashcroft, B. (2010). Extending Shift-Share Decomposition through Cluster Analysis: An Application to New Firm Formation in British Counties. Economics \& Management Discussion Papers.

Rahmaddi, R., \& Ichihashi, M. (2012). The Changing Pattern of Export Structure and Competitiveness in Indonesia's Manufacturing Sectors: An Overview and Assessment. In 2nd International Conference on Economics (pp. 7-11). Trade and Development IPEDR.

Rahman, M. K., Aflah, N., Chowdhury, N. A., \& Khan, A. H. (2014). Shift Share Analysis of Malaysia's Export on Natural Rubber. International Journal of Business and Applied Science, 1(1), 1-12.

Rupasingha, A., \& Patrick, J. M. (2009). Tools for Understanding Economic Change in Communities: Economic Base Analysis and Shift-Share Analysis.

Slater, S. F., Hult, G. T., \& Olson, E. M. (n. d.). (2010). Factors influencing the relative importance of marketing strategy creativity and marketing strategy implementation effectiveness. Industrial Marketing Management, 39(4), 551-559. http://dx.doi.org/10.1016/j.indmarman.2008.03.007

Talib, B. A., \& Darawi, Z. (2002). An economic analysis of the Malaysian palm oil market. Oil Palm Industry Economic Journal, 2(1), 19-27.

Türkekul, B., Günden, C., Abay, C., \& Miran, B. (2007). A market share analysis of virgin olive oil producer countries with special respect to competitiveness. European Association of Agricultural Economics (EAAE).

Zaccomer, G. P. (2011). New spatial shift-share decomposition for the regional growth analysis: a local study of the employment based on Italian Business Statistical Register. Statistical Methods \& Applications, 20(3), 329-356. http://dx.doi.org/10.1007/s10260-011-0160-5

\section{Copyrights}

Copyright for this article is retained by the author(s), with first publication rights granted to the journal.

This is an open-access article distributed under the terms and conditions of the Creative Commons Attribution license (http://creativecommons.org/licenses/by/3.0/). 